Bangladesh J. Bot. 38(2): 171-176, 2009 (December)

\title{
SEED MORPHOLOGY AND HISTOLOGY OF SOME PARONYCHIA TAXA (CARYOPHYLLACEAE) FROM TURKEY
}

\author{
Ayşe Kaplan", Hatice Çölgeçen and H. Nurhan Büyükkartal ${ }^{1}$ \\ Department of Biology, Faculty of Arts and Science, Zonguldak Karaelmas University, \\ 67100 Incivez, Zonguldak, Turkey
}

Key words: Paronychia, Caryophyllaceae, Seed morphology, Seed histology, Turkey

\begin{abstract}
Seed morphology and histology of 12 taxa (nine species, two subspecies, one variety) of Paronychia Miller (Caryophyllaceae) by light and scanning electron microscopes revealed that seeds are laterally compressed, reniform, and hilums are linear. Testa surface structures are alveolate-scalariform, colliculate, reticulate-alveolate, rugose and ruminate. Differences in cuticle and papillae properties of epidermal cells have been observed. A dichotomous key has been developed for Paronychia agryloba Stapf, P. angorensis Chaudri, P. arabica (L.) DC. subsp. euphratica Chaudri, P. carica Chaudri, $P$. cataonica Chaudri, $P$. condensata Chaudri, P. davisii Chaudri, P. dudleyi Chaudri, P. galatica Chaudri, P. kurdica Boiss subsp. kurdica var. kurdica, P. kurdica Boiss subsp. montis-munzur Chaudri and P. mughlaei Chaudri.
\end{abstract}

\section{Introduction}

The genus Paronychia Miller (Caryophyllaceae) is distributed in warm and dry regions of the world (Willis 1966, Perveen and Qaiser 2003, Soltis et al. 2005). In Turkey the plants are found in Irano-Turanien and East-Mediterranian phytogeographic regions and is represented by 28 species, 20 of which are endemic to Turkey \& East Aegean Islands (Davis 1967, Güner et al. 2000). In the Red data book of turkish plants, the status of 12 endemic Paronychia species has been described (Ekim et al. 2000).

Seed morphology of some genera of Caryophyllaceae have been studied (Yildiz 2002) In Arenaria uniflora, seed surface was smooth with entire cell margins in this species grown in wet regions, whilst seed surface was corrugate with sinuate testa cell margins when plants grown in dry regions (Wyatt 1984). Seeds of Silene species were generally tuberculate (Yıldız and Çırpıcı 1998, Y1ld1z 2005). In some species of Saponaria, seed surface structures were colliculate or flat tuberculate (Ataşlar 2004, Çinbilgel et al. 2007). Seed morphology of 15 species of Sagina was studied by Crow (1979). There was variation in particular surface features within some members of the genus. Two basic seed types occured in this genus and were diagnostic at the sectional level. The saginoid seed, characteristic of section Sagina, was obliquely triangular in outline, was grooved along the two dorsal ridges, and had slightly concave lateral surfaces. The crassuloid seed, characteristic of section Maxima, was obliquely reniform, lacked dorsal grooves and had shallowly convex lateral surfaces (Crow 1979). Study of the Turkey's species Paronychia is limited. Only pollen morphology was studied by Kaplan (2008). In the present study, seed morphology and histology of 12 endemic taxa of the genus Paronychia, present in Turkey were investigated.

\section{Materials and Methods}

Seed samples of 12 endemic Paronychia taxa, such as P. agryloba Stapf, P. angorensis Chaudri, P. arabica (L.) DC. subsp. euphratica Chaudri, $P$. carica Chaudri, $P$. cataonica Chaudri, $P$. condensata Chaudri, P. davisii Chaudri, P. dudleyi Chaudri, P. galatica Chaudri, P. kurdica Boiss subsp. kurdica var. kurdica, P. kurdica Boiss subsp. montis-munzur Chaudri and

*Correspondence author. E-mail: aysekaplan2003@hotmail.com ${ }^{1}$ Department of Biology, Faculty of Science, Ankara University, 06100 Tandoğan, Ankara, Turkey. 
P. mughlaei Chaudri were collected from Herbarium specimens of Gazi University (GAZI) and Hacettepe University (HUB). Detailed information of these are given in Table 1. Samples were placed on double cellotape on the aluminum stabs, coated with gold by means of Polaron SC500 Sputter Coater and coating was restricted to $30 \mathrm{~mA}$ for $4 \mathrm{~min}$. They were investigated by JEOL GSM 5600 and LEO 435 VP SEM's.

Table 1. Detail of herbarium specimens of Paronychia Miller considered in the present study, along with the status ${ }^{\mathrm{a}}$.

\begin{tabular}{|c|c|c|c|}
\hline Sl. No. & Herbarium specimens and status ${ }^{\mathrm{a}}$ & Collector(s) & Herbarium number(s) \\
\hline 1. & P. agryloba Stapf (LR) & H. Sümbül, 1981 & GAZI, 1124, HUB 1124 \\
\hline 2. & P. angorensis Chaudri (VU) & R.D.Reeves \& U. Kramer & GAZI, 1606 \\
\hline 3. & $\begin{array}{l}\text { P. arabica (L.) DC. } \\
\text { subsp. euphratica Chaudri (VU) }\end{array}$ & H. Peşmen \& A. Güner & HUB, 2237 \\
\hline 4. & P. carica Chaudri (VU) & Z. Aytaç \& N. Adıgüzel & GAZI, 1995 \\
\hline 5. & P. cataonica Chaudri (VU) & H. Duman \& Z. Aytaç & GAZI, 51976 \\
\hline 6. & P. condensata Chaudri (LR) & M. Vural, Ü. Kol, N. Adıgüzel & GAZI, 4876 \\
\hline 7. & P. davisii Chaudri (EN) & H. Özçelik, 1995 & GAZI, H. Özçelik-7107 \\
\hline 8. & P. dudleyi Chaudri (LR) & Z. Aytaç \& H. Duman,1994 & GAZI, 5197a \\
\hline 9. & P. galatica Chaudri (LR) & E. Hamzaoğlu, 1992 & GAZI, EH-477 \\
\hline 10. & $\begin{array}{l}\text { P. kurdica Boiss } \\
\text { subsp. kurdica var. kurdica (VU) }\end{array}$ & Ü. Güler, 1993 & GAZI, 1157 \\
\hline 11. & $\begin{array}{l}\text { P. kurdica } \text { Boiss } \\
\text { subsp. montis-munzur Chaudri (VU) }\end{array}$ & Ş. Y1ldırımlı & HUB, 3492 \\
\hline 12. & P. mughlaei Chaudri (VU) & H. Peşmen \& A. Güner & HUB, 1686 \\
\hline
\end{tabular}

${ }^{\mathrm{a}} \mathrm{EN}=$ Endangered, $\mathrm{VU}=$ Vulnerable, $\mathrm{LR}=$ Low risk.

Seeds were soaked in distilled water for $12 \mathrm{~h}$ for taking semi-thin sections. These were then fixed at $3 \%$ glutaraldehyde buffered with $0.1 \mathrm{M}$ phosphate $(\mathrm{pH} 7.2)$ for $3 \mathrm{~h}$ at room temperature. They were then post-fixed with buffered $1 \%$ osmium tetraoxide for $3 \mathrm{~h}$ at room temperature. The materials were dehydrated through a graduated ethanol series and embedded in Epon 812 (Luft 1961). Semi-thin $(1.5$ or $2 \mu \mathrm{m})$ sections were cut and stained with $1 \%$ methylene blue or $1 \%$ safranin. These sections were photographed by Leica DFC 280 digital camera. The terminology described by Stearn (2004) was used to describe seed coat surface sculpturing.

\section{Results and Discussion}

Seeds of 12 taxa of Paronychia are latterally compressed, reniform and the hilums are linear. Seed coat surface characteristics of the taxa are given in Table 2. Of the 12 taxa P. agryloba, $P$. angorensis and $P$. arabica were with non-papillate epidermis, rest of the taxa are papillate (Figs 2a-e). Ornamentations of the testa are categorized into five types such as alveolate-scalariform, colliculate, reticulate-alveolate, rugose and ruminate, distribution of which among the 12 taxa is shown in Table 2 and SEM of ornamentations in Figs 1a-l.

Among the 12 taxa of Paronychia, ruminate and colliculate seed surface ornamentations were common. Alveolate-scalariform and reticulate-alveolate seed surface ornamentations are reported for the first time in the family Caryophyllaceae. Photomicrographs of papillate and non-papillate testa among the 12 taxa are given in Figs $2 \mathrm{a}$-e and 3a-g, respectively.

Paronychia taxa is distributed in Inner and West Anatolia regions of Turkey as well as in the Mediterranean region. P. dudleyi, $P$. arabica subsp. euphratica, $P$. condensata and $P$. angorensis are Irano-Turanien elements, and $P$. davisii and $P$. mughlaei are East-Mediterranean elements 
(Davis 1967). The thickest cuticle is present in P. arabica subsp. euphratica $(10 \mu \mathrm{m})$ while thinnest cuticle is present in $P$. mughlaei $(1.3 \mu \mathrm{m})$. Considering the relationship between seed morphological properties and growing areas of studied taxa, it can be said without generalization that Paronychia taxa growing in the Mediterranean region have thin cuticle, while those growing in Inner and East Anatolia have thick ones.
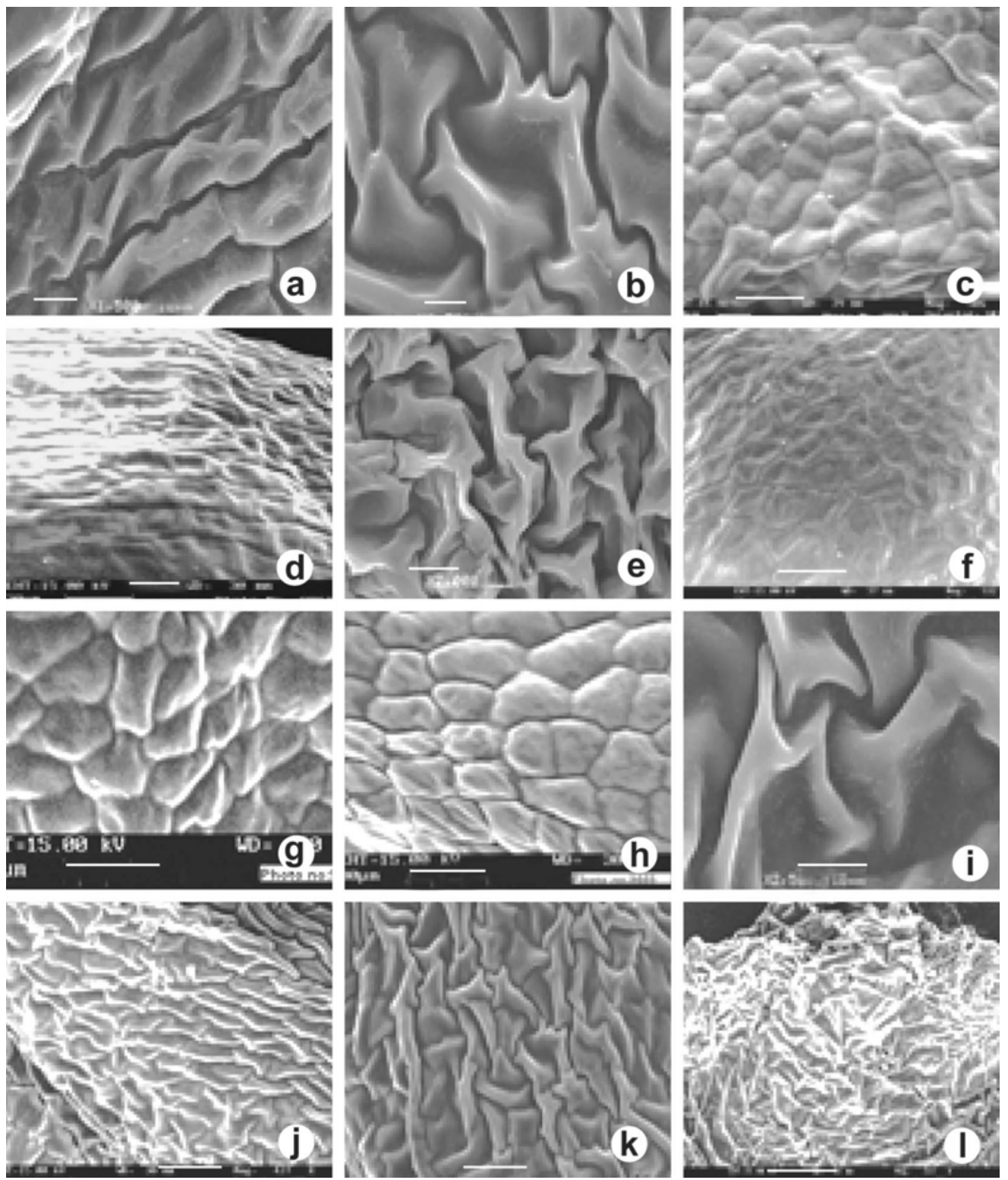

Fig. 1 a-1. Surface ornamentations (SEM) of testa of Paronychia taxa. (a) P. agryloba, (b) P. angorensis. (c) P. arabica subsp. euphratica, (d) P. carica, (e) P. cataonica, (f) P. condensata, (g) P. davisii, (h) $P$. dudleyi, (i) P. galatica, (j) P. kurdica subsp. kurdica var. kurdica, (k) P. kurdica subsp. montis-munzur, (1) P. mughlaei. 
Table 2. Morphological and histological properties of seed 12 of Paronychia taxa.

\begin{tabular}{|c|c|c|c|c|}
\hline Taxa & $\begin{array}{l}\text { Seed coat } \\
\text { surface }\end{array}$ & $\begin{array}{l}\text { Cuticle } \\
\text { thickness } \\
(\mu \mathrm{m} \pm \mathrm{s} . \mathrm{d} .)\end{array}$ & Papilla & Epidermis \\
\hline P. agryloba & Rugose & $3.4 \pm 0.4$ & absent & Epidermis smooth \\
\hline P. angorensis & Ruminate & $1.4 \pm 0.2$ & absent & Epidermis convex \\
\hline $\begin{array}{l}\text { P. arabica } \\
\text { subsp. euphratica }\end{array}$ & Colliculate & $10 \pm 0.3$ & absent & $\begin{array}{l}\text { Epidermal cells have dense } \\
\text { cytoplasm }\end{array}$ \\
\hline P. carica & $\begin{array}{l}\text { Alveolate- } \\
\text { scalariform }\end{array}$ & $2.9 \pm 0.2$ & present & $\begin{array}{l}\text { Epidermal cells have dense } \\
\text { cytoplasm }\end{array}$ \\
\hline P. cataonica & Ruminate & $2.3 \pm 0.0$ & absent & $\begin{array}{l}\text { Outer layer of epidermis is } \\
\text { compressed }\end{array}$ \\
\hline P. condensata & $\begin{array}{l}\text { Reticulate- } \\
\text { alveolate }\end{array}$ & $2.7 \pm 0.0$ & present & Epidermis convex \\
\hline P. davisii & Colliculate & $2.0 \pm 0.1$ & absent & $\begin{array}{l}\text { Epidermis smooth, cells with } \\
\text { dense cytoplasm }\end{array}$ \\
\hline P. dudleyi & Colliculate & $2.4 \pm 0.1$ & present & Epidermis with acute papillae \\
\hline P. galatica & Ruminate & $1.5 \pm 0.2$ & present & Epidermal cells are big \\
\hline $\begin{array}{l}\text { P. kurdica } \\
\text { subsp. kurdica var. kurdica }\end{array}$ & Ruminate & $3.1 \pm 0.4$ & absent & Epidermis convex \\
\hline $\begin{array}{l}\text { P. kurdica } \\
\text { subsp. montis-munzur }\end{array}$ & Ruminate & $2.1 \pm 0.3$ & absent & Epidermis convex and zigzag \\
\hline P. mughlaei & Rugose & $1.3 \pm 1.1$ & present & Epidermis has acute papillae \\
\hline
\end{tabular}
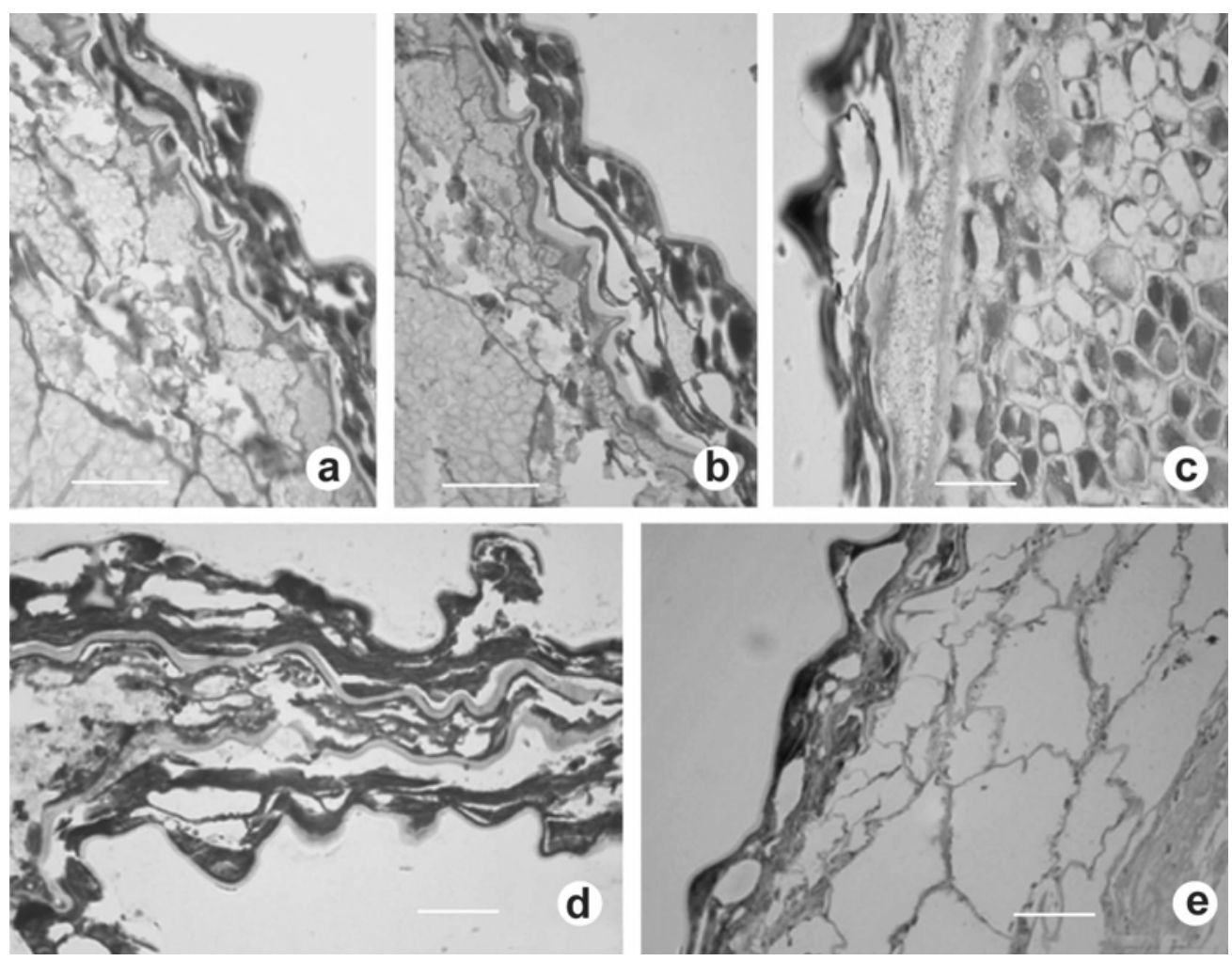

Fig. 2 a-e. Cross-sections of papillate testa of Paronychia taxa. a. P. dudleyi, b. P. carica, c. P. condensata, d. P. galatica, e. P. mughlaei. Bars $=20 \mu \mathrm{m}$. 

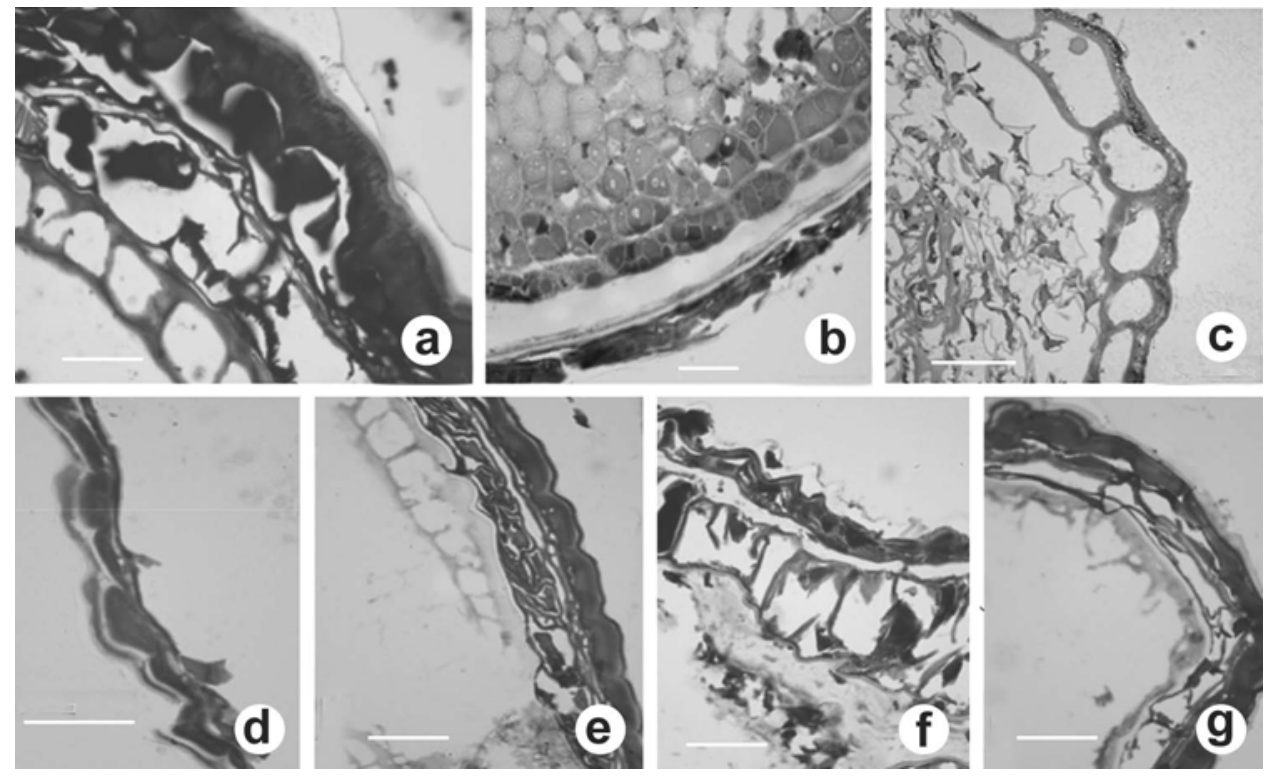

Fig. 3 a-g. Cross-sections of non papillate testa of Paronychia taxa. a. P. arabica subsp. euphratica, b. P. davisii, c. P. agryloba, d. P. kurdica subsp. kurdica var. kurdica, e. P. cataonica, f. P. kurdica subsp. montis-munzur, g. P. angorensis. Bars $=20 \mu \mathrm{m}$.

Seed coat characters, such as cuticle layer, papillae features of epidermis, ornamentations of testa surface, etc. of Paronychia have been found to be useful taxonomic characters in the identification of species. Based on these taxonomic characters, a dichotomous key has been prepared for 12 Paronychia taxa as follows:

\title{
Key to 12 taxa of Paronychia based on coat characters:
}

\author{
Upper surface of epidermis has papillae \\ Upper surface of epidermis has no papillae \\ Seed surface colliculate, cuticle thickness about $2.40 \mu \mathrm{m}$ \\ Seed surface otherwise \\ Cuticle more than $1.50 \mu \mathrm{m}$ \\ Cuticle $1.50 \mu \mathrm{m}$ or less \\ Seed surface alveolate-scalariform \\ Seed surface reticulate-alveolate \\ Seed surface ruminate \\ Seed surface rugose \\ Seed surface colliculate \\ Seed surface otherwise \\ Cuticle very thick about $10 \mu \mathrm{m}$ \\ Cuticle thickness about $2.00 \mu \mathrm{m}$ \\ Seed surface rugose cuticle thickness about $3.40 \mu \mathrm{m}$ \\ Seed surface ruminate \\ Epidermal cells convex \\ Epidermal cells otherwise \\ 10 Cuticle thickness about $3.10 \mu \mathrm{m}$ \\ 10 Cuticle thickness about $1.40 \mu \mathrm{m}$ \\ 11 Epidermal cells compressed \\ 11 Epidermal cells convex and zigzag in shape
}
2
6
P. dudleyi
3
4
5
P. carica
P. condensata
P. galatica
P. mughlaei
7
8
P. arabica subsp. euphratica
P. davisii
P. agryloba
10
11
P. kurdica subsp. kurdica var. kurdica
P. angorensis
P. cataonica
P. kurdica subsp. montis-munzur




\section{Acknowledgements}

Authors are deeply grateful to Prof. Dr. Mecit Vural, Gazi University, Assoc. Prof. Dr. Ali Dönmez and Prof. Dr. Şinasi Yıldırımlı, Hacettepe University for their kind support during this research and for their permission of using herbarium specimens. Thanks are due to the staff of SEM Laboratory of Kırıkkale University and Turkish Cement Association for their help in the SEM studies. The research project was supported by Turkish Scientific Research Council (TUBITAK) (Project no: TBAG-106T213-HD/150) which is gratefully acknowledged.

\section{References}

Ataşlar E. 2004. Morphological and anatomical investigations on the Saponaria kotschyi Boiss. (Caryophyllaceae). Turkish J. Bot. 28: 193-199.

Crow G.E. 1979. The systematic significance of seed morphology in Sagina (Caryophyllaceae) under scanning electron microscope. Brittonia 31: 52-63.

Çinbilgel İ., A. Karadeniz and M. Gökceoğlu. 2007. Morphological and anatomical study on endemic Saponaria pamphylica Boiss. \& Heldr. (Carypohyllaceae). J. Appl. Biol. Sci. 1: 19-25.

Davis P.H. 1967. Flora of Turkey and the East Aegean Islands. Vol. 2: 245-260. Edinburgh Univ. Press, Edinburgh.

Ekim T., M. Koyuncu, H. Duman, Z. Aytaç and N. Adıgüzel. 2000. Red data book of turkish plants (Pteridophyta and Spermatophyta). Barışcan Ofset, Ankara. 94 pp.

Güner A., N. Özhatay, T. Ekim and K.H. Canbaser. 2000. Flora of Turkey and the East Aegean Islands, Volume 11. Univ. Press, Edinburgh. 53 pp.

Kaplan A. 2008. Pollen morphology of some Paronychia species (Caryophyllaceae) from Turkey. Biologia 63: $53-60$.

Luft J.H. 1961. Improvements in epoxy resin embedding methods. J. Biophys. Bioch. Cytol. 9: 109-115.

Perveen A. and M. Quaiser. 2003. Pollen Flora of Pakistan- Illecebraceae. Pak. J. Bot. 35: 141-144.

Soltis D.E., P. Soltis, P.K. Endress and M.W. Chase. 2005. Phylogeny and evolution of Angiosperms. Sinauer Associates Inc., Sunderland.

Stearn W.T. 2004. Botanical Latin. Timber Press, North America. pp. 489-491.

Willis J.C. 1966. A dictionary of the flowering plants \& ferns. Cambridge Univ. Press, London. pp. 203-204.

Wyatt R. 1984. Intraspecific variation in seed morphology of Arenaria uniflora (Caryophyllaceae). System. Bot. 9: 423-431.

Yildiz K. and A. Çırpıcı. 1998. Seed morphological studies in Silene L. from Turkey. Pak. J. Bot. 33: 13-25.

Yildiz K. 2002. Seed morphology of Caryophyllaceae species from Turkey (Northern Anatolia). Pak. J. Bot. 34: 161-171.

Yildiz K. 2005. Morphological and palynological investigations on Silene gigantea L. var. gigantea and Silene behen L. (Caryophyllaceae) distributed in western Anatolia and northern Cyprus. Turkish J. Bot. 30: 105-119. 